\title{
The Hemopoietic Effect of Nuclear Extractives in Human Anemias
}

\author{
By N. W. Jones, M.D., B. I. Phillips, M.D., Olof Larsele, Ph.D., and \\ H. T. Nokis, M.D., Portland, Oregon \\ (From the Departments of Anatomy and Medicine, University of Oregon \\ Medical School)
}

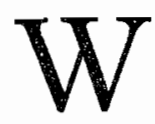

ITH no more than passing reference (I, 2, 3, 4) to the experimental work upon which the following clinical studies have been founded, we wish in this paper to relate briefly observations we have made on the effect of nuclear extractives in the treatment of anemia in human patients. The nuclear extractives used, as reported elsewhere, have been obtained by the methods of Hammarsten and of Kossel-Neumann from various organ sources, and have been considered to be nucleo-proteins and the sodium salts of nucleic acids. An unknown hemopoietic stimulant exists in both of these nuclear extractives, and because from both experimental and clinical suggestive evidence we have thought a greater effect upon blood regeneration was seen from the use of both extractives in combination than from the use of either one alone, we have administered to anemic patients capsules containing one-fourth gram of each extractive. In the earlier part of the clinical work we employed the intravenous injection of from onefourth to one gram of the sodium salts

*Aided by grant No. 128 from the Committee on Medical Research of the American Medical Association. of nucleic acids obtained from the washed nuclei of the blood cells of the fowl. There was observed, however, in about one-half of the patients so treated, a serum-like reaction of sufficient degree to make this method objectionable. In consequence, oral administration of the extractives was adopted with seemingly the same effect upon the blood picture.

In the entire study thus far made we have obtained nuclear extractives from eight different organs; and the percentages of extractives obtained per given weight of organ substance has been as follows: chicken corpuscles about 3 per cent, beef spleen 2.4 per cent, beef liver I. 8 per cent, beef kidney 0.9 per cent, beef heart muscle 0.5 per cent, salmon liver 2.4 per cent, beef thymus per cent and beef pancreas per cent not determined. All of the above extractives, with the exception of those obtained from beef heart muscle, have been used in the produced anemia of experimental animals. The animals have shown the same type of response in reticulated cells, hemoglobin content and in red blood cell counts that has been seen in anemic animals and in human patients with pernicious anemia to whom a high 
liver diet has been administered. The hemoglobin and in the red cell count hemopoietic stimulation observed, how- was observed in most of them. ever, has seemingly shown a more definite relation to the quantity of extractives administered than to the organ from which they were obtained. The best results followed the administration of extractives from chicken corpuscles and the next most marked results from the use of extractives from beef spleen and from salmon liver. Both of the latter extractives gave better responses than did those from beef liver. For an as yet unknown reason the extractives from thymus have given the least response of all. In the anemias of human patients we have employed thus far the extractives obtained from chicken blood cells, beef liver and beef spleen, and we have seen in these patients, for the most part, similar effects upon the blood production.

Nuclear Extractives Obtained FROM T'HEE WASHED NUCLEI OF ChICKenN BLOOD CELLS

It was found experimentally that the hemopoietic stimulant existed only in the nucleus of the chicken blood cell. The cytoplasm of the cell alone -and consequently the hemoglobin element of the cell-possessed no power to stimulate blood formation in the animal body. It was from the washed nticlei of the blood cells, therefore, that we obtained the first nuclear extractives used in this series of studies.

Tables I and II, respectively, give, briefly, the important data in a series of pernicious anemia patients and in a series of patients having secondary anemias. A temporary slight rise in
Patient No. I, table I, suffered a severe reaction from the intravenous administration of the extractives, and his blood counts showed no temporary rise in hemoglobin and red cells, as the blood of the other two patients did show. This patient had had a splenectomy done some months before. We have seen the same response from the intravenous injection of similar nuclear extractives in splenectomized rabbits. The third patient showed no more effect from the long continued use of liver than she had temporarily shown in response to the injection of $0.5 \mathrm{gm}$. sodium nucleate. In a similar way the patients having chronic secondary anemias showed usually a temporary rise in hemoglobin and red cell content in response to one administration of sodium nucleate. In patient No. 2, bleeding uterine fibroids seemingly prevented any rise, and there was also no effect upon the blood seen from the use of liver. In patient No. 5 a temporary rise in blood count was seen to follow each of two injections of 0.25 gm. doses.

The effect of the oral adninistration of nuclear extractives obtained from whole chicken blood and the effect of the oral administration of the washed nuclei themselves is now being studied and a report of these observations will be made later. FROM BEEF LIVER

A larger number of patients with anemia have been treated clinically by us with the nuclear extractives ob-

\section{Nuclear Extractives ObTained}

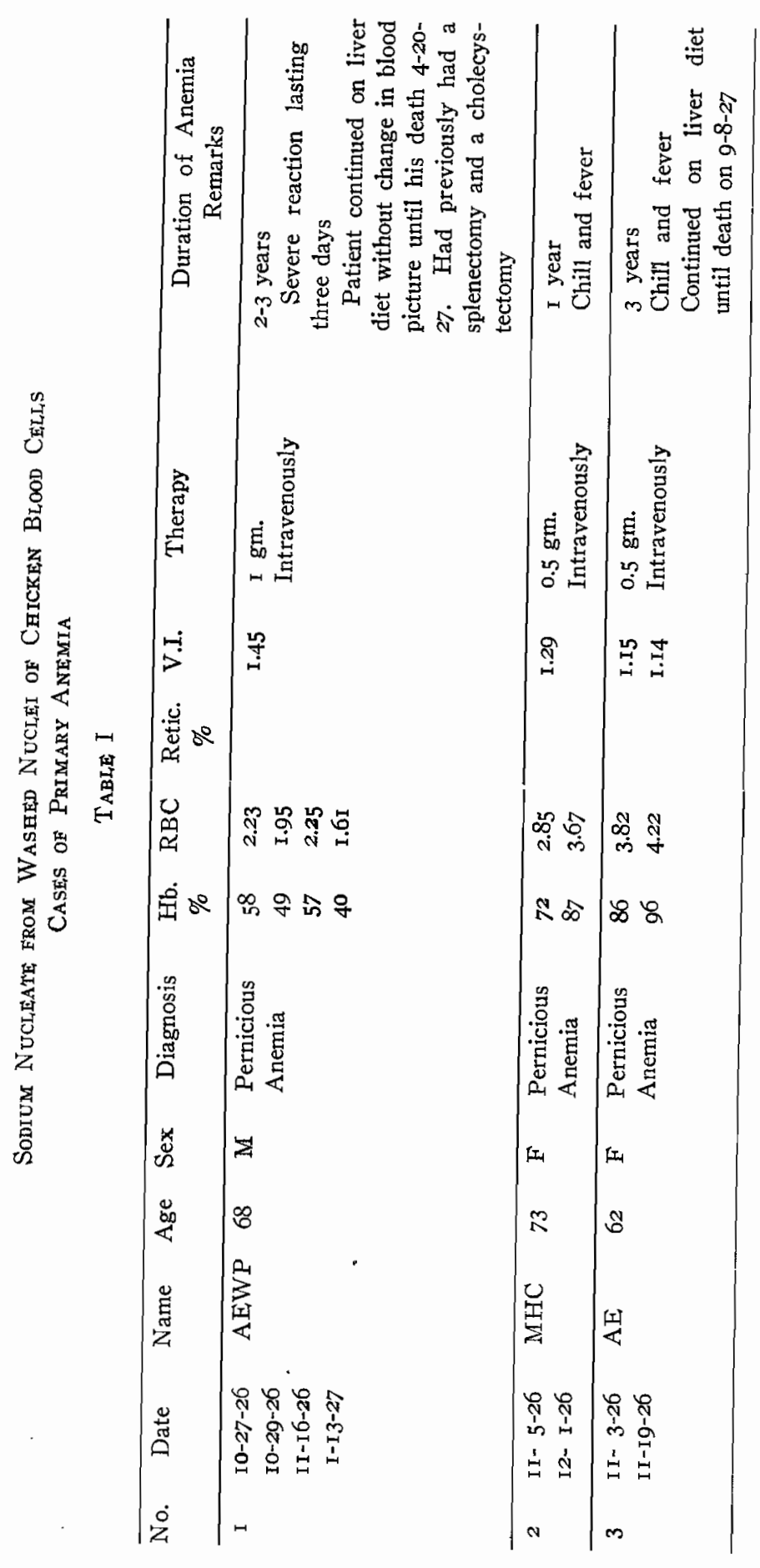


tained from other sources than chick- person with pernicious anemia. Comen blood cells, and especially from pare, for example, in table IV, cases beef liver, because of the greater Nos. 5, 6, 7, 8, 9, IO, II, I2, I4, I5 ease of manufacturing them in quan- and 16 . Rough clinical controls have tity and also because of the present been run as of cases Nos. Io-A, I3-A, interest in the liver treatment of I4-A, I5-A, and I6-A. The identical pernicious anemia. (See tables III twins, Nos. 13 and I3-A were under and IV, and graphs $I, 2$, and 3 ). We observation and control very unsatishave been able in several instances factorily but an obvious improvement to run like cases as rough clinical was noted in the treated patient over controls. We have also on several the progress of the untreated one. occasions treated a given patient with The anemia of chronic cholecystitis nuclear extractives from liver, from did not seemingly respond much until spleen and by liver feeding for after the gallbladder was removed. stated periods of time to compare if Then, however, the patient treated possible the relative stimulant effect with nuclear extractives, or with liver of the different substances. In the feeding, seemingly regained a normal main, both in the case of primary blood content and a clinical recovery anemia and in that of secondary more rapidly than the patient not so anemia like effects have been noted. treated. The same statement may be Our study of pernicious anemia pa- made in regard to patients with anemia tients during the past year has shown due to uterine fibroids, hyperplastic a variation in individual response sinusitis, etc. This point is stressed seemingly due to the fact that a num- because there is now a widespread ber of the patients had been eating suspicion that the use of liver or its liver before coming to us. In these extractives holds a certain specificity patients the rise in the reticulated for pernicious anemia and that percells has been modified or absent. sons suffering from secondary anemias Case 6, table III, illustrates this are unimproved by their use. This point well. Case 7 indicates the ne- suspicion is wholly at variance with cessity of using sufficiently large doses of the extractives.

Patients with secondary anemias showed a less uniform response to the administration of nuclear extractives, and to liver feeding, than did patients suffering from pernicious anemia. However, those patients who had suffered an acute anemia from hemorrhage, from an acute and transitory infection, or even in certain instances in which the cause has not been recognized, have shown quite as dramatic a response to treatment as any our experience. Surely case No, 6 belies this assumption, for the child had been treated for months with dietetic and medicinal measures without effect and the use of $3 \mathrm{gm}$. daily of nuclear extractives for a period of seven weeks produced quite as noteworthy a response in blood content and clinical recovery as could be seen in pernicious anemia. We have been of the opinion that the probable cause of failure to gain on the part of some persons with secondary anemia lies in the relative balance be- 
SODIUM NUCLEATE AND NUCLFOPROTEIN FROM LIVER Cases of Primary ANemia

TABLE III

\begin{tabular}{|c|c|c|c|c|c|c|c|c|c|c|c|}
\hline No. & Date & Name & Age & Sex & Diagnosis & $\begin{array}{l}\mathrm{Hb} . \\
\%\end{array}$ & $\mathrm{RBC}$ & $\begin{array}{l}\text { Retic. } \\
\%\end{array}$ & V.I. & Therapy & $\begin{array}{l}\text { Duration of Anemia } \\
\text { Remarks }\end{array}$ \\
\hline I & $\begin{array}{r}\text { I I-28-27 } \\
\text { I } 2-\text { I0-27 } \\
\text { I2-I 5-27 } \\
\text { I- 9-28 } \\
3-22-28\end{array}$ & $\mathrm{JE}$ & 80 & $\mathrm{M}$ & $\begin{array}{l}\text { Pernicious } \\
\text { Anemia }\end{array}$ & $\begin{array}{l}35 \\
35 \\
43 \\
72 \\
83\end{array}$ & $\begin{array}{l}1.15 \\
2.26 \\
2.26 \\
3.68 \\
3.79\end{array}$ & & & $\begin{array}{l}450 \mathrm{cc} \text {. whole blood } \\
450 \mathrm{cc} \text {. whole blood } \\
\text { I } \mathrm{gm} \text {. tid increased } \\
\text { to } 2 \mathrm{gm} \text {. tid in one } \\
\text { week }\end{array}$ & $\begin{array}{l}44 \text { years } \\
\text { Left hospital feeling well }\end{array}$ \\
\hline 2 & $\begin{array}{l}2-8-28 \\
2-15-28 \\
2-22-28 \\
2-24-28\end{array}$ & WL, & 62 & $\mathbf{M}$ & $\begin{array}{l}\text { Pernicious } \\
\text { Anemia }\end{array}$ & $\begin{array}{r}4 \mathrm{I} \\
43 \\
73 \\
104\end{array}$ & $\begin{array}{l}1.73 \\
2.08 \\
3.16 \\
5.12\end{array}$ & $\begin{array}{r}\mathrm{I} .3 \\
8.0 \\
24.0 \\
2.0\end{array}$ & 1.23 & $2 \mathrm{gm} . \mathrm{tid}$ & $\begin{array}{l}\text { Second relapse of anemia } \\
\text { Graph No. I } \\
\text { Left hospital feeling well }\end{array}$ \\
\hline 3 & $\begin{array}{l}\mathrm{I}-29-28 \\
\mathrm{I}-26-28 \\
\mathrm{I}-30-28 \\
2-28-28 \\
3-26-28\end{array}$ & $\mathrm{EC}$ & & $M$ & $\begin{array}{l}\text { Pernicious } \\
\text { Anemia }\end{array}$ & $\begin{array}{l}38 \\
43 \\
50 \\
90 \\
90\end{array}$ & $\begin{array}{l}\text { I. } 26 \\
\text { I.43 } \\
2.04 \\
4.36 \\
4.40\end{array}$ & & & $\begin{array}{l}\text { I gm. tid } \\
2 \mathrm{gm} . \text { tid } \\
3 \mathrm{gm} . \text { tid }\end{array}$ & Continues to feel well \\
\hline 4 & $\begin{array}{l}2-2-28 \\
2-23-28 \\
2-27-28 \\
3-12-28 \\
3-26-29\end{array}$ & OP & & $M$ & $\begin{array}{l}\text { Pernicious } \\
\text { Anemia }\end{array}$ & $\begin{array}{l}28 \\
25 \\
28 \\
57 \\
80\end{array}$ & $\begin{array}{l}1.03 \\
0.97 \\
1.02 \\
2.28 \\
3.19\end{array}$ & & & $\begin{array}{l}\text { High protein diet-- } \\
\text { profoundly ill } \\
\text { Iron citrate } \\
4 \mathrm{gmn} \text { tid-started } \\
6 \mathrm{gm} . \text { tid }\end{array}$ & $\begin{array}{l}\text { Marked clinical improve- } \\
\text { ment }\end{array}$ \\
\hline
\end{tabular}

- TABLE III, Continued

\begin{tabular}{|c|c|c|c|c|c|c|c|c|c|c|c|}
\hline 5 & $\begin{array}{l}4-13-27 \\
4-15-27 \\
4-18-27\end{array}$ & $\mathrm{KAD}$ & 79 & $F$ & $\begin{array}{l}\text { Pernicious } \\
\text { Anemia }\end{array}$ & $\begin{array}{l}56 \\
62 \\
70\end{array}$ & $\begin{array}{l}2.14 \\
2.30 \\
2.07\end{array}$ & & $\mathrm{I} .33$ & $2 \mathrm{gm}$. tid & $\begin{array}{l}\text { Acute relapse for } 2 \text { wks. } \\
\text { Death-with rising hemo- } \\
\text { globin }\end{array}$ \\
\hline is & $\begin{array}{l}3-\mathrm{I} 4-28 \\
3-2 \mathrm{I}-28 \\
3-30-28 \\
4-\mathrm{I} 3-28 \\
4-28-28\end{array}$ & ELP & 42 & & $\begin{array}{l}\text { Hyperplastic } \\
\text { Sinusitis } \\
\text { Dental sepsis } \\
\text { Pern. Anemia? }\end{array}$ & $\begin{array}{r}\mathrm{I} \text { I4 } \\
\\
93 \\
? \begin{array}{l}87 \\
8 \mathrm{I} \\
90\end{array}\end{array}$ & $\begin{array}{l}4.50 \\
4.43 \\
4.17 \\
4.21 \\
4.10\end{array}$ & $\begin{array}{l}0.3 \\
6 .\end{array}$ & $\begin{array}{l}\text { I.I4 } \\
\text { I.I4 }\end{array}$ & $\begin{array}{l}\text { Previous } \\
\text { liver feeding } \\
\text { and liver } \\
\text { extracts } \\
\text { Off liver I week } \\
\text { Off liver } 2 \text { weeks } \\
3 \text { gm. tid }\end{array}$ & $\begin{array}{l}\text { Weakness, dizziness and } \\
\text { anemia, since Nov. I927 } \\
\text { Radical antrum op. } \\
\text { Dental extraction } \\
\text { Marked clinical improve- } \\
\text { ment }\end{array}$ \\
\hline 7 & $\begin{array}{r}9-10-27 \\
9-20-27 \\
10-1-27 \\
10-10-27 \\
10-29-27 \\
\text { I I-12-27 } \\
11-25-27 \\
12-20-27\end{array}$ & LHS & & $\mathbf{M}$ & $\begin{array}{l}\text { Pernicious } \\
\text { Anemia } \\
\text { Diabetes }\end{array}$ & $\begin{array}{r}42 \\
4 \mathrm{I} \\
6 \mathrm{I} \\
66 \\
83 \\
90 \\
9 \mathrm{I} \\
100\end{array}$ & \begin{tabular}{l|}
1.47 \\
1.32 \\
1.88 \\
2.35 \\
3.25 \\
3.58 \\
4.17 \\
3.82
\end{tabular} & & & $\begin{array}{l}\text { I gm. tid } \\
\text { I.5 gm. tid }\end{array}$ & $\begin{array}{l}\text { Marked clinical improve- } \\
\text { ment }\end{array}$ \\
\hline
\end{tabular}


SODIUM NUChEATE AND NUCLEOIROTEIN FROM LIVER

Cases of Secondary Anemta

TABIE IV

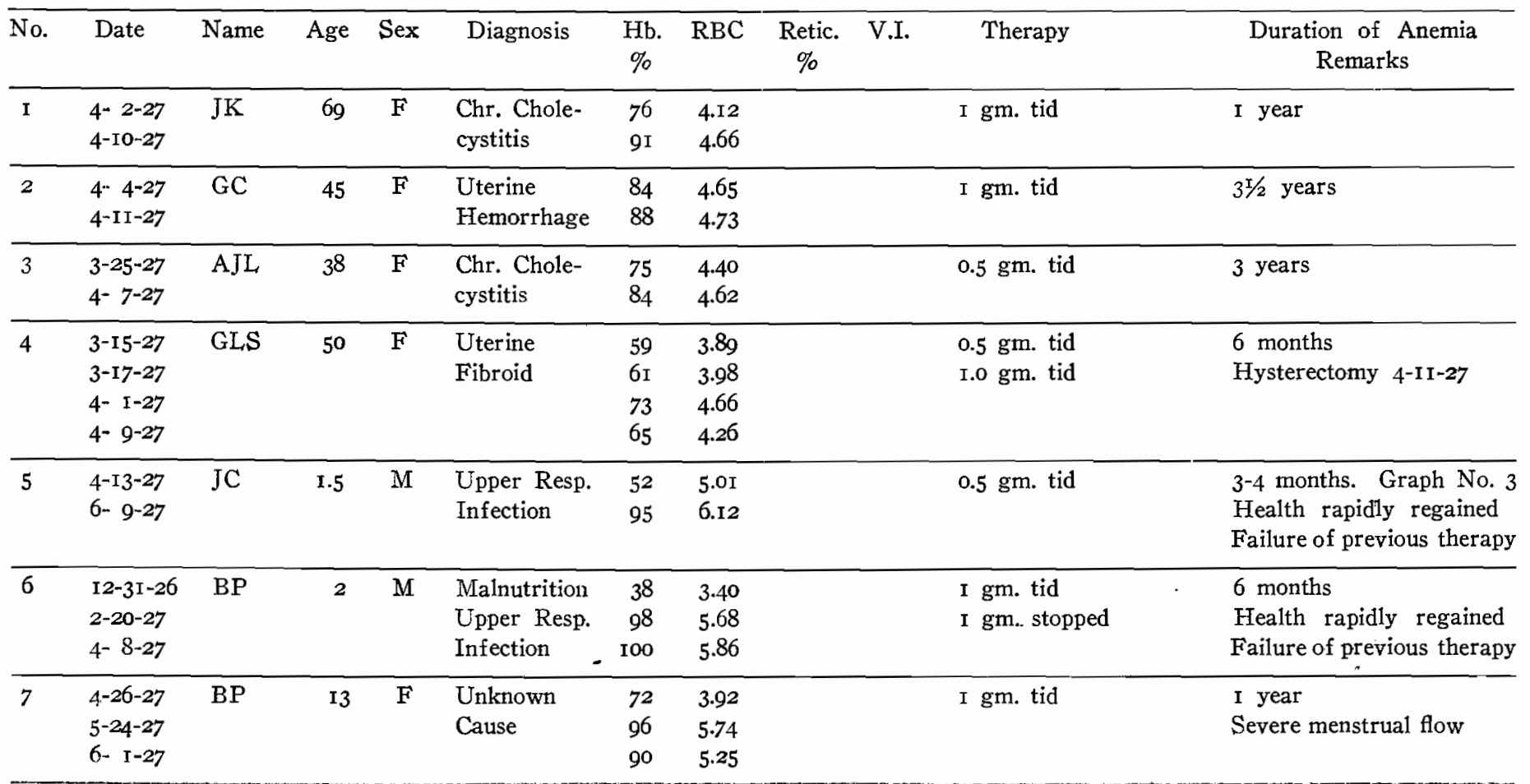

TABLE IV, Continued

\begin{tabular}{|c|c|c|c|c|c|c|c|c|c|c|}
\hline 8 & $\begin{array}{l}5-19-27 \\
6-9-27\end{array}$ & $W$ & 24 & $\mathbf{F}$ & $\begin{array}{l}\text { Unknown } \\
\text { Cause }\end{array}$ & $\begin{array}{l}57 \\
92\end{array}$ & $\begin{array}{l}3.95 \\
5.24\end{array}$ & & 0.6 gm. tid & 2-3 years, periodically \\
\hline 9 & $\begin{array}{l}7-18-27 \\
7-25-27 \\
8-20-27 \\
8-22-27 \\
9-10-27\end{array}$ & LR & 26 & $\mathbf{F}$ & $\begin{array}{l}\text { Hemorrhage } \\
\text { Peptic Ulcer }\end{array}$ & $\begin{array}{l}20 \\
38 \\
74 \\
58 \\
94\end{array}$ & $\begin{array}{l}1.4 \mathrm{I} \\
2.64 \\
4.42 \\
3.60 \\
5.24\end{array}$ & & $\begin{array}{l}550 \mathrm{cc} \text {. whole blood } \\
\text { I gm. tid }\end{array}$ & $\begin{array}{l}\text { Acute onset } \\
\text { Gastroenterostomy } \\
\text { Discharged }\end{array}$ \\
\hline Io & $\begin{array}{l}8-3-27 \\
8-29-27 \\
9-13-27\end{array}$ & IW & I9 & $\mathrm{F}$ & $\begin{array}{l}\text { Hemorrhage } \\
\text { Abortion }\end{array}$ & $\begin{array}{l}32 \\
64 \\
95\end{array}$ & $\begin{array}{l}1.95 \\
3.40 \\
5.24\end{array}$ & & 2 gm. tid & $\begin{array}{l}\text { Acute onset } \\
\text { Discharged }\end{array}$ \\
\hline I0-A & $\begin{array}{r}8-30-27 \\
9-30-27 \\
10-8-27\end{array}$ & Mrs. D & 28 & $\mathbf{F}$ & $\begin{array}{l}\text { Hemorrhage } \\
\text { Abortion }\end{array}$ & $\begin{array}{l}5 I \\
64 \\
68\end{array}$ & $\begin{array}{l}2.98 \\
3.89 \\
4.00\end{array}$ & $\begin{array}{l}3 \\
4\end{array}$ & Curettement & $\begin{array}{l}\text { Acute onset } \\
\text { Used as control } \\
\text { Discharged }\end{array}$ \\
\hline I I & $\begin{array}{l}2-22-28 \\
3-6-28 \\
3-20-28 \\
4-2-28\end{array}$ & $\mathrm{CB}$ & 47 & M & $\begin{array}{l}\text { Lobar } \\
\text { Pneumonia }\end{array}$ & $\begin{array}{l}\text { III } \\
48 \\
60 \\
86\end{array}$ & $\begin{array}{l}5.28 \\
3.52 \\
4.08 \\
6.08\end{array}$ & $\begin{array}{r}12 \\
3\end{array}$ & $2 \mathrm{gm} . \mathrm{tid}$ & $\begin{array}{l}\text { Anemia following lobar } \\
\text { pneumonia } \\
\text { Graph No. } 2 \\
\text { Discharged }\end{array}$ \\
\hline $\mathrm{I} 2$ & $\begin{array}{l}8-7-27 \\
8-17-27\end{array}$ & $\mathrm{~L} Z$ & 45 & M & $\begin{array}{l}\text { Cellulitis } \\
\text { of Thigh }\end{array}$ & $\begin{array}{l}48 \\
95\end{array}$ & $\begin{array}{l}3.02 \\
5.14\end{array}$ & & 2 gm. tid & $\begin{array}{l}\text { Anemia following cellulitis } \\
\text { Discharged }\end{array}$ \\
\hline
\end{tabular}


TABIE IV, Continued

\begin{tabular}{|c|c|c|c|c|c|c|c|c|c|}
\hline 13 & $\begin{array}{r}\text { I0-12-27 } \\
\text { I I-14-27 } \\
\text { I-II-28 }\end{array}$ & Martha & I & F & $\begin{array}{l}\text { Nutritional } \\
\text { Disturbance }\end{array}$ & $\begin{array}{l}38 \\
50 \\
55\end{array}$ & $\begin{array}{l}2.96 \\
4.20 \\
4.80\end{array}$ & I gm. tid & Identical twins \\
\hline I3-A & $\begin{array}{r}\text { I0-12-27 } \\
\text { II-I } 4-27 \\
\text { I-II-28 }\end{array}$ & Mary & I & $\mathbf{F}$ & $\begin{array}{l}\text { Nutritional } \\
\text { Disturbance }\end{array}$ & $\begin{array}{l}38 \\
40 \\
40\end{array}$ & $\begin{array}{l}3.19 \\
3.80 \\
4.70\end{array}$ & Dietetic tr. only & Used as a control \\
\hline 14 & $\begin{array}{r}12-9-27 \\
12-15-27 \\
12-20-27 \\
1-11-28 \\
I-17-28\end{array}$ & FA & 22 & $\mathrm{M}$ & $\begin{array}{l}\text { Hemorrhage } \\
\text { Peptic Ulcer }\end{array}$ & $\begin{array}{l}19 \\
30 \\
50 \\
75 \\
89\end{array}$ & $\begin{array}{l}1.28 \\
2.30 \\
3.22 \\
4.98 \\
5.24\end{array}$ & $\begin{array}{l}500 \mathrm{cc} \text {. whole blood } \\
2 \mathrm{gm} \text {. tid }\end{array}$ & $\begin{array}{l}\text { Acute onset } \\
\text { Marked clinical improve- } \\
\text { ment }\end{array}$ \\
\hline I4-A & $\begin{array}{r}12-20-27 \\
\mathrm{I} 2-23-27 \\
\mathrm{I}-\mathrm{I} \mathrm{I}-28 \\
\mathrm{I}-\mathrm{I} 7-28\end{array}$ & CB & 32 & $\mathrm{M}$ & $\begin{array}{l}\text { Pulmonary } \\
\text { Hemorrhage } \\
\text { Cause } \\
\text { Unknown }\end{array}$ & $\begin{array}{l}40 \\
36 \\
40 \\
46\end{array}$ & $\begin{array}{l}2.52 \\
2.62 \\
3.03 \\
3.24\end{array}$ & & $\begin{array}{l}\text { Acute onset } \\
\text { Case used as a control } \\
\text { Slow recovery }\end{array}$ \\
\hline I5 & $\begin{array}{l}8-7-27 \\
8-10-27 \\
8-17-27\end{array}$ & $\mathrm{LZ}$ & 21 & $\mathbf{F}$ & $\begin{array}{l}\text { Following } \\
\text { Acute Peri- } \\
\text { tonitis }\end{array}$ & $\begin{array}{l}52 \\
84 \\
96\end{array}$ & $\begin{array}{l}3.02 \\
4.37 \\
5.14\end{array}$ & $2 \mathrm{gm} . \mathrm{tid}$ & $\begin{array}{l}\text { Acute onset } \\
\text { Rapid recovery }\end{array}$ \\
\hline $\mathrm{I}_{5}-\mathrm{A}$ & $\begin{array}{l}8-26-27 \\
8-28-27 \\
8-31-27\end{array}$ & LH & I9 & $\mathbf{F}$ & $\begin{array}{l}\text { Acute } \\
\text { Hemorrhage, } \\
\text { Abortion }\end{array}$ & $\begin{array}{l}30 \\
40 \\
58\end{array}$ & $\begin{array}{l}1.92 \\
2.10 \\
2.50\end{array}$ & $\begin{array}{l}\text { Transfused } \\
\text { whole blood }\end{array}$ & $\begin{array}{l}\text { Acute onset } \\
\text { Used as control } \\
\text { Slower recovery }\end{array}$ \\
\hline
\end{tabular}

TABLE IV, Continued

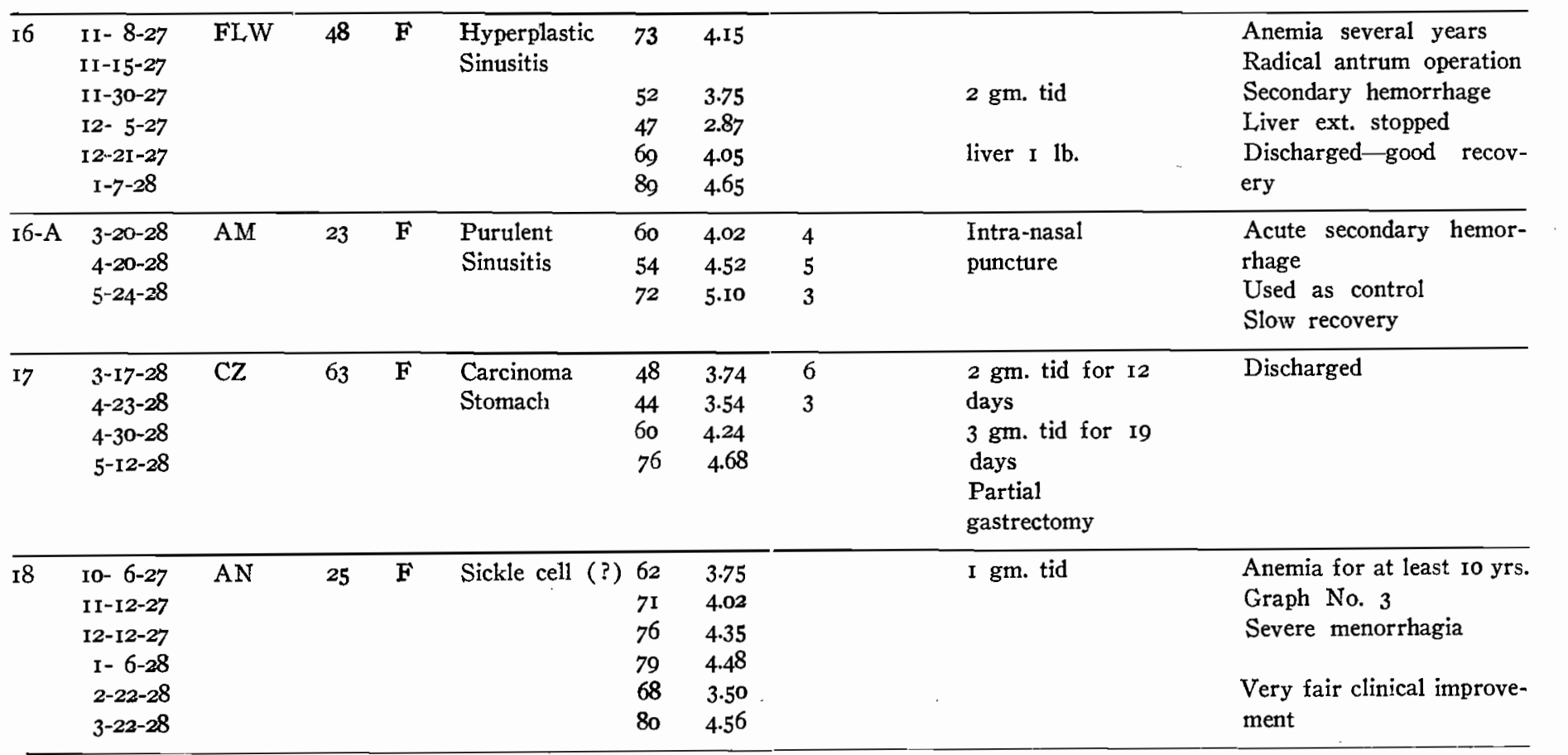




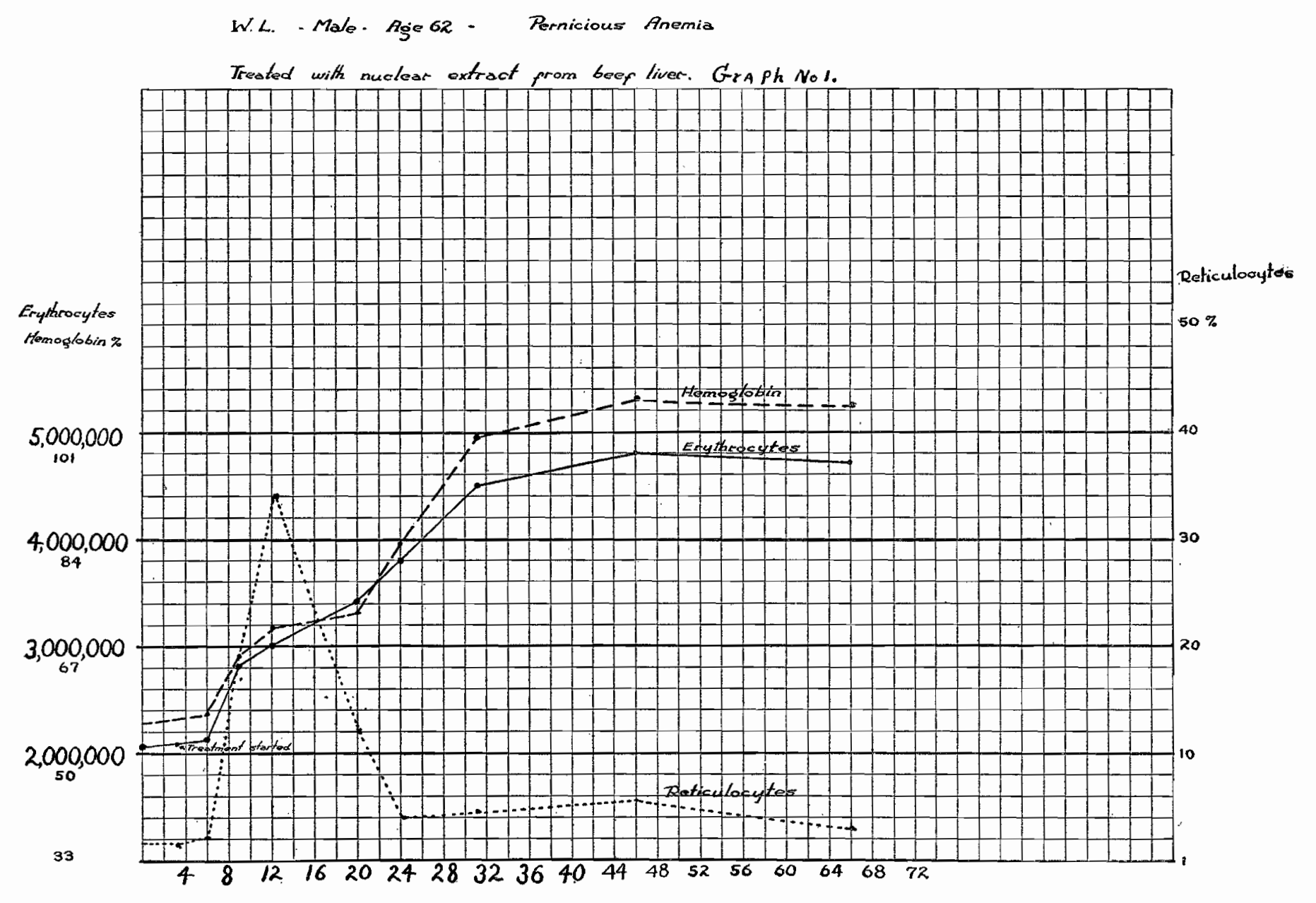

$\frac{a}{1}$

Z

\&

过

蛋

$\square$

$-$

몰

客

.

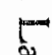

$\stackrel{D}{\stackrel{D}{0}}$

I

-

궁

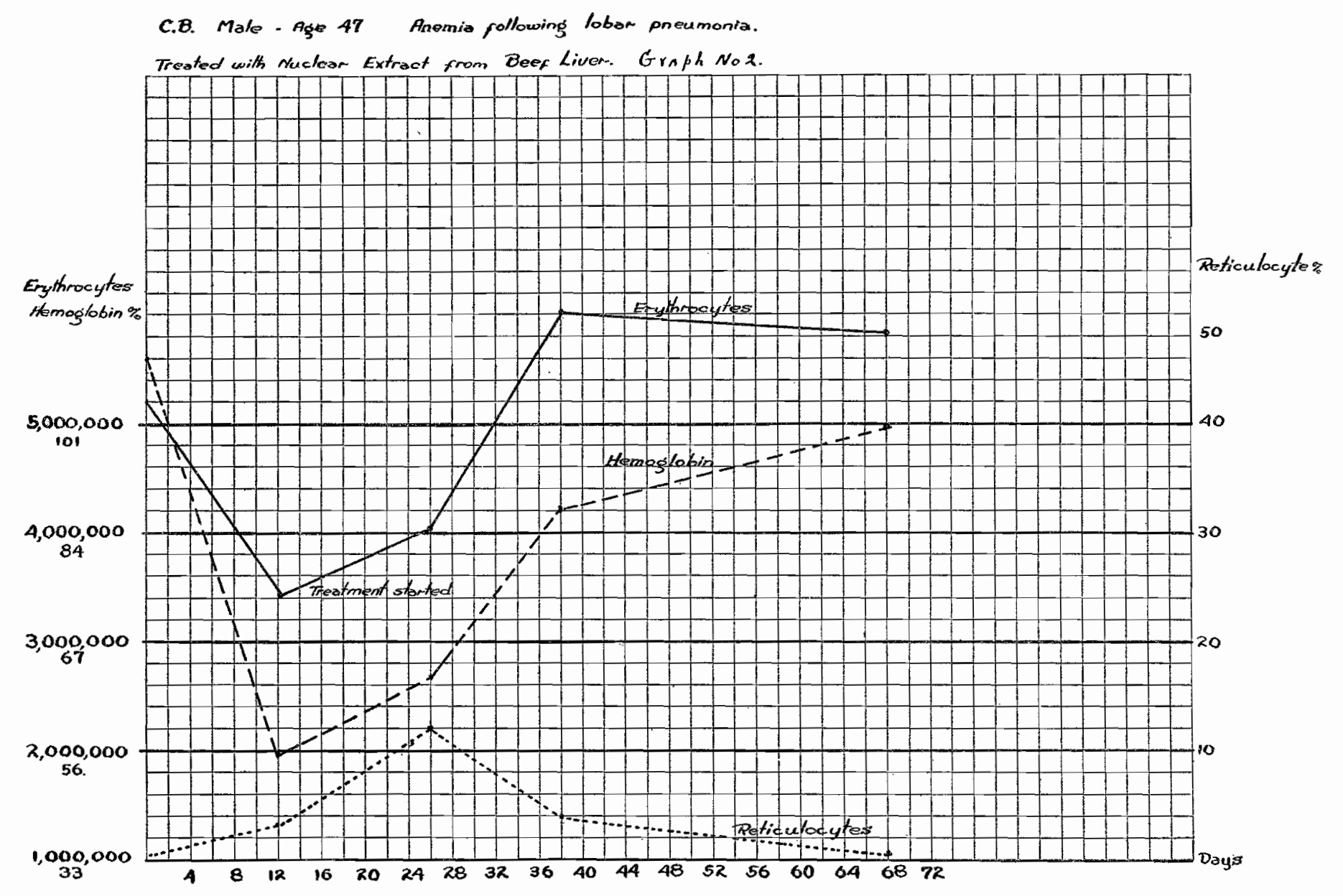




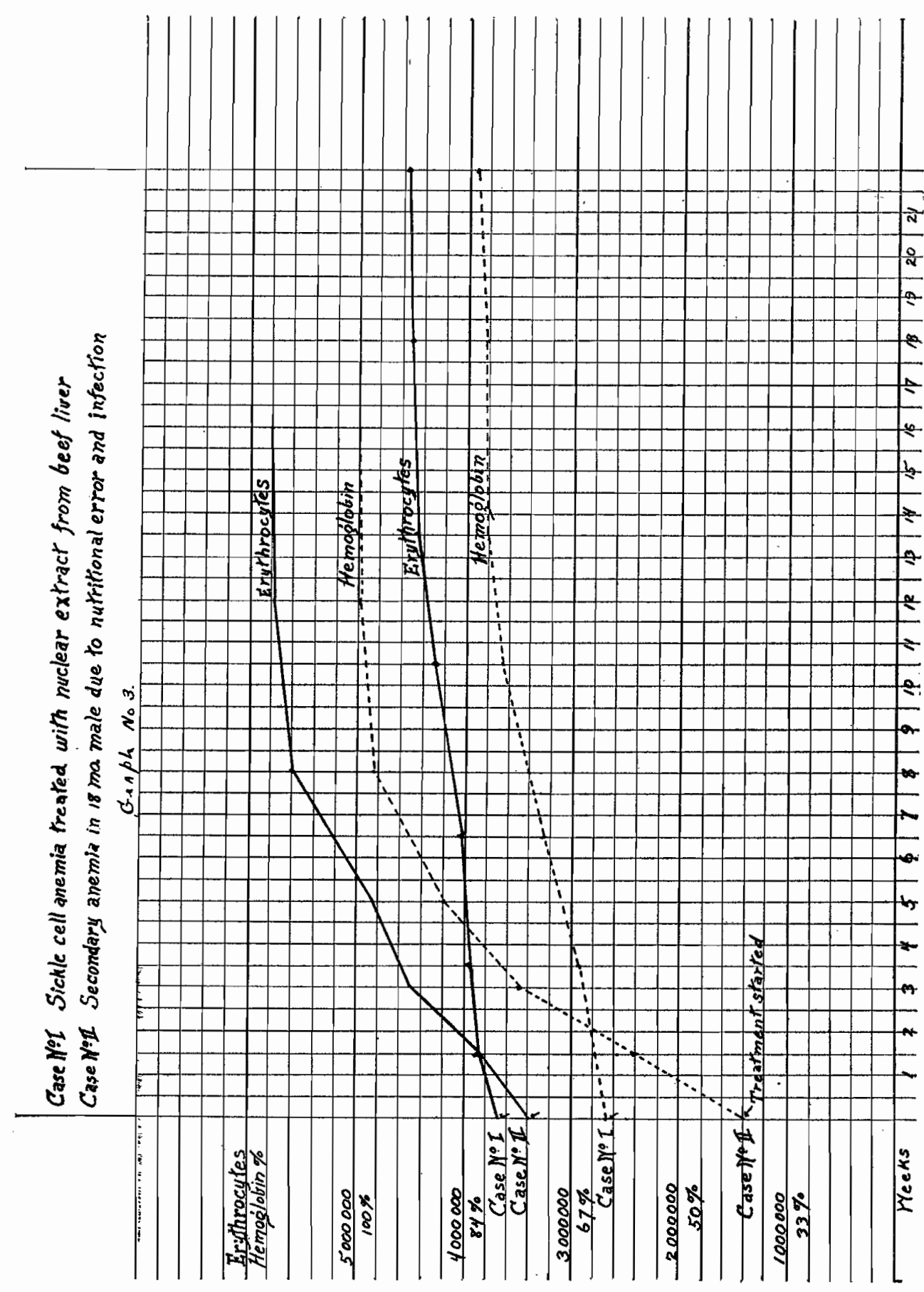

tween the cause of the anemia operating and the capacity of the hemopoietic centers of the bone marrow to respond to stimulation. Case No. I7, a woman with carcinoma of the stomach, made no gain on $6 \mathrm{gm}$. nuclear extractives daily in 12 days, but after partial gastrectomy, showed a gain of $32 \%$ hemoglobin and I.I4 million red cells on $9 \mathrm{gm}$. of the same extractives in 19 days. The control cases IO-A, I4-A, I5-A and I6-A might suggest that the patient would not have shown this gain had she not been so treated.

Case No. I 8 , a young white woman suffering from a chronic anemia which simulated sickle cell anemia (to be reported by Drs. Hunter and Adams from the Department of Pathology, University of Oregon) showed marked clinical improvement under the administration of $I \mathrm{gm}$. liver extractives three times daily. Gastrointestinal distress disappeared, the pallor of her skin and mucous membranes became much less marked and the hemoglobin and red cell content progressively increased, over a period of five months, from 62 to 80 per cent and 3.75 million to 4.56 million respectively. Under no other form of treatment had improvement ever been observed.

\section{Nuclear Extractives Obtainted} FROM BEEF SPLEEN

Six patients suffering from pernicious anemia have been treated by the use of sodium nucleates and nucleoproteins obtained from beef spleen. A resumé of their data is given in table V. Graph No. 4 illustrates the progress under treatment of patient No. I. Two patients present the same initial rise in reticulocyte count the rapid gain in hemoglobin and red blood cell content, and the same clincal improvement observed from high ver feeding. Patients No. 2 and 3 had previously eaten liver, and the increase of the reticulated cells was elayed and less high than in patients Nos. I and 4 who had not eaten liver. Patient No. 2 was given spleen extractives, $9 \mathrm{gm}$. for 4 days and I2 gm. for I4 days, with a rise of I $5 \%$ hemoglobin; then liver extractives gm. for I 5 days, with a rise of $22 \%$ hemoglobin; then spleen extractives $9 \mathrm{gm}$. for 9 days with a rise of $5 \%$ hemoglobin, at which time she returned home on liver feeding. $\mathrm{Pa}$ tient No. 3 was given 9 gm. spleen extractives for I4 days and showed gain of $14 \%$ hemoglobin; then gm. liver extractives for 4 days with a gain of $5 \%$ hemoglobin, then for Io days, 9 ounces of raw liver was given, with a gain of $4 \%$ hemoglobin, and finally for a period of 21 days 3 vials of Lilly's liver extract were added to the 9 ounces of raw liver with a ain of $5 \%$ hemoglobin. The numbness and tingling of the hands and feet, from which this patient suffered, did not disappear. We have seen the paresthesia disappear twice in pernicious anemia patients; once from liver feeding and once from the use of the nuclear extractives obtained from spleen. For the most part, however, we have seen no effect upon the symptoms of cord lesions.

Discussion. In presenting at this time this brief report of our clinical observations on the use of nuclear extractives obtained from different ani- 
Sodium Nucleate AND Nucleofrotein From SPLeEN

Cases of Primary Anemia

TABLE V

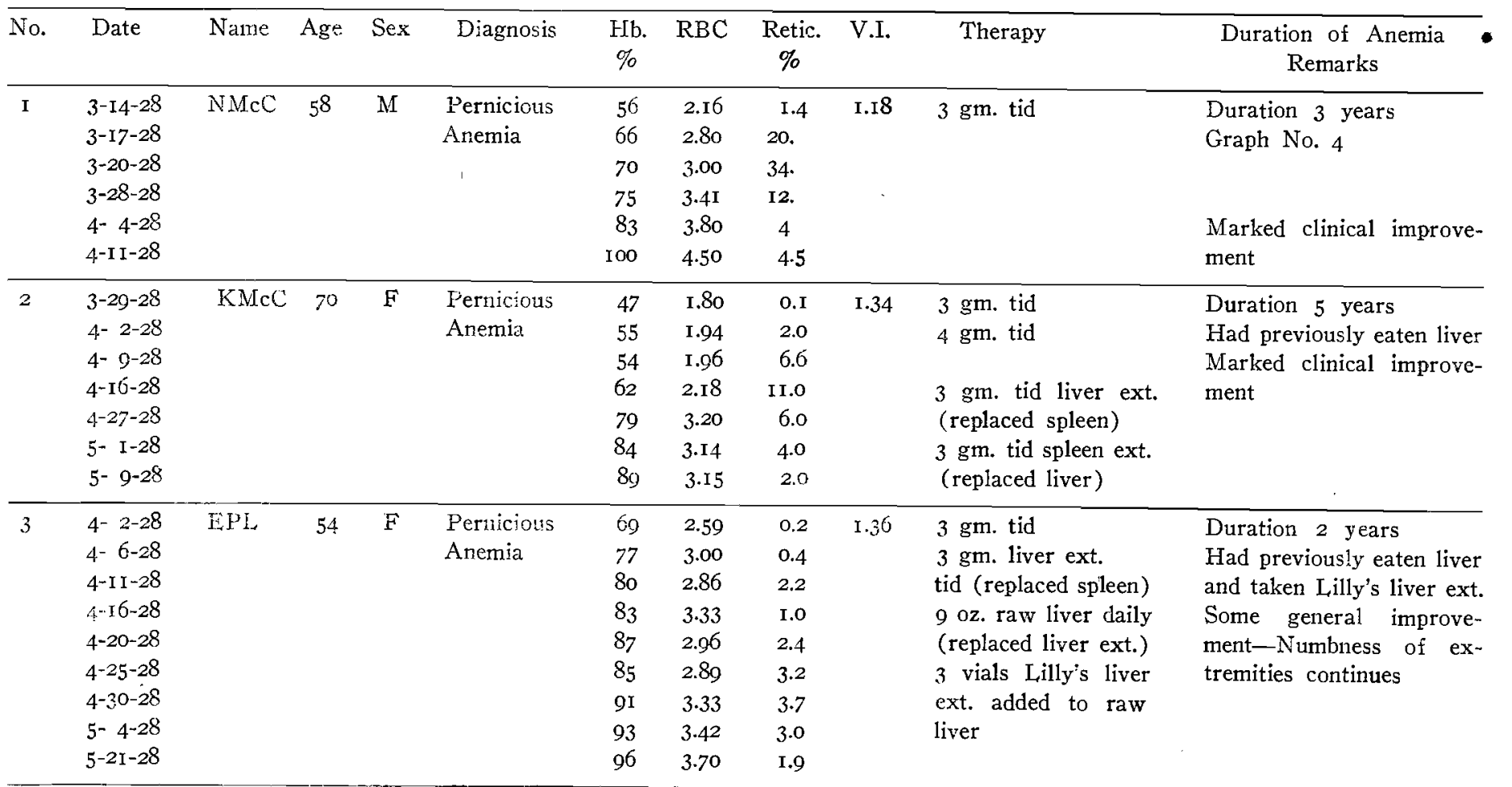

$T_{\text {ABLE }} \mathrm{V}$, Continued

\begin{tabular}{|c|c|c|c|c|c|c|c|c|c|c|c|}
\hline 4 & $\begin{array}{l}4-22-28 \\
4-30-28 \\
5-8-28 \\
5-22-28\end{array}$ & AA & 72 & $F$ & $\begin{array}{l}\text { Pernicious } \\
\text { Anemia }\end{array}$ & $\begin{array}{l}58 \\
66 \\
74 \\
90\end{array}$ & $\begin{array}{l}1.86 \\
2.37 \\
3.06 \\
4.03\end{array}$ & $\begin{array}{r}\text { I.6 } \\
\text { I I.0 } \\
\text { I } 4.0 \\
8.0\end{array}$ & 1.52 & $3 \mathrm{gm} . \mathrm{tid}$ & $\begin{array}{l}\text { Duration (?) } \\
\text { Marked clinical improve- } \\
\text { ment }\end{array}$ \\
\hline 5 & $\begin{array}{l}6-15-28 \\
6-21-28 \\
6-29-28\end{array}$ & $\mathrm{GP}$ & 72 & $\mathrm{~F}$ & $\begin{array}{l}\text { Pernicious } \\
\text { Anemia }\end{array}$ & $\begin{array}{l}28 \\
33 \\
46\end{array}$ & $\begin{array}{l}0.90 \\
\text { I. } 40 \\
2.46\end{array}$ & $\begin{array}{r}7.8 \\
10.0 \\
9.0\end{array}$ & $\mathrm{I} .22$ & $3 \mathrm{gm} . \mathrm{tid}$ & $\begin{array}{l}\text { Duration several months } \\
\text { Marked clinical improve- } \\
\text { ment }\end{array}$ \\
\hline 6 & $\begin{array}{l}5-21-28 \\
6-1-28 \\
6-15-28 \\
6-21-28 \\
6-20-28\end{array}$ & ST & 55 & $F$ & $\begin{array}{l}\text { Pernicious } \\
\text { Anemia }\end{array}$ & $\begin{array}{l}45 \\
58 \\
64 \\
80 \\
84\end{array}$ & $\begin{array}{l}1.80 \\
1.96 \\
2.21 \\
3.42 \\
3.49\end{array}$ & $\begin{array}{r}1.0 \\
4.0 \\
\mathrm{I} 3.4 \\
7.0 \\
5.0\end{array}$ & $\begin{array}{l}\text { I.I7 } \\
\text { I.I } 4\end{array}$ & $3 \mathrm{gm} . \mathrm{tid}$ & $\begin{array}{l}\text { (Started } 5-25-28 \text { ) } \\
\text { Marked parasthesias } \\
\text { All parasthesias gone } \\
\text { Marked clinical improve- } \\
\text { ment }\end{array}$ \\
\hline
\end{tabular}




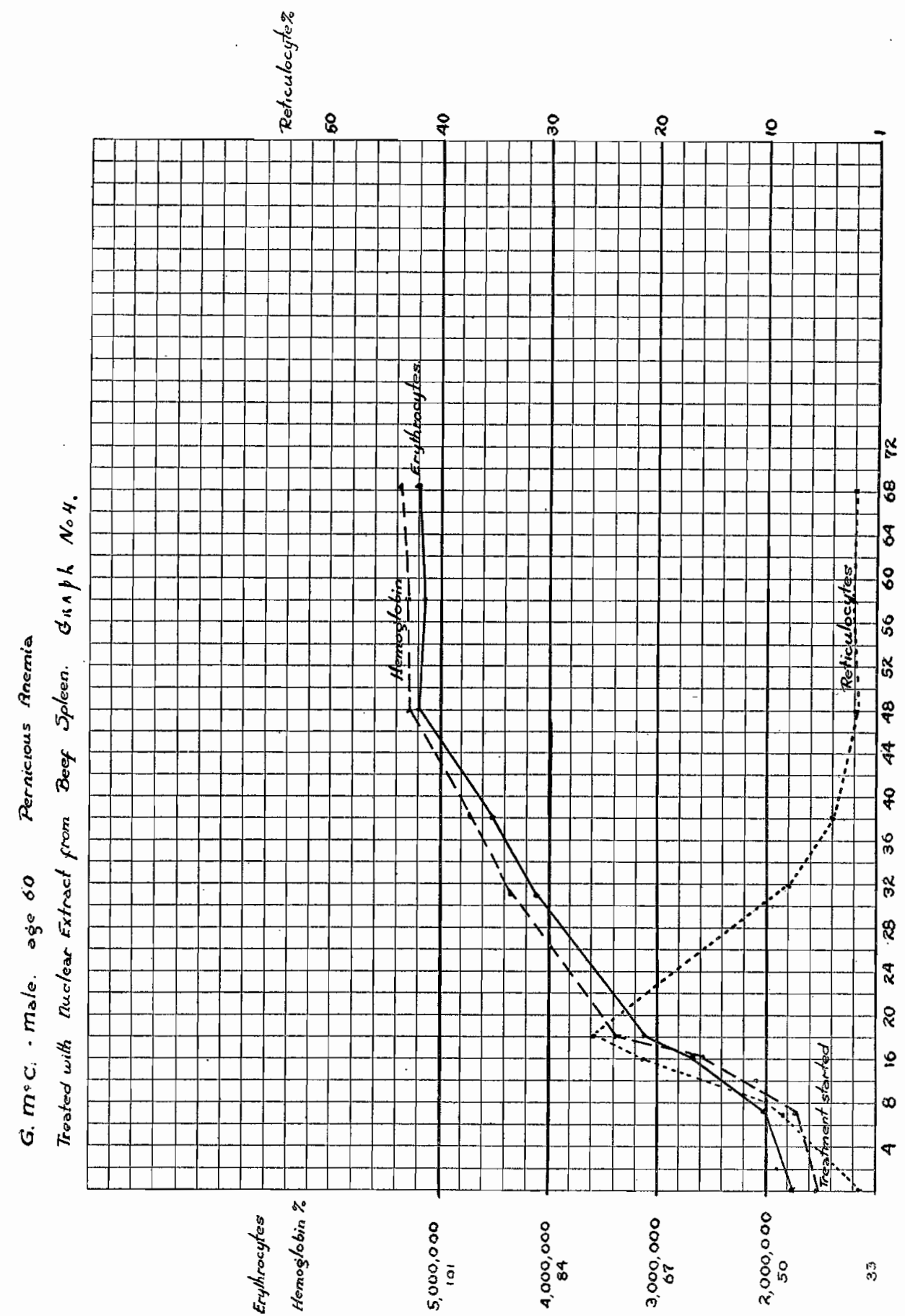

mal sources in the treatment of human that the effect noted upon blood proanemias, we havc been actuated mainly by the fact that our experience is at variance with the clinical reports thus far published by others. The experimental work of Leake, Bacon and Evans, Robscheit-Robbins and Whipple and by ourselves (5), and the results obtained by McCann (6), all point to the belief that there are one or more factors common to bone marrow, spleen, liver, chicken blood cells, kidney, etc., which have similar hemopoietic effects upon the animal body. Nuclear extractives are common to all of these substances. The facts that such extractives obtained from the washed nuclei of chicken blood cells have this hemopoietic stimulant effect markedly and that the cytoplasm of the blood cell cloes not possess it at all are especially suggestive.

If we can tentatively conclude anything from our limited work, both clinical and experimental, it is that the hemopoietic stimulant, unknown as yet as to its composition, is an integral part of the cell nucleus, and

\section{REFERENCES}

(I) Arch. Path. \& Lab. Med, I926, ii :698703.

(5) Cited and reported: J. A. M. A., I928, (2) J. A. M. A, $1927,1 \mathrm{xxxix}: 682-685$

(3) J. A. M. A., I928, xc:75-78.
(4) Proc. Soc. Exp. Biol. \& Med., Ig28, $\mathrm{xxv}$ :No. 9. $x c: 75-78$ uction from the taking of different nimal tissues depends upon the in that particular meat eaten. Iive shown, in our experimental work, greater stimulant effect than panspleen; and the greatest effect, far noted, has been obtaine the washed nuclei of the blood the fowl. A practical may be suggested from this obnamely, that liver alone, which is often repugnant to persons, may be replaced by the eating of kidsweetbreads, spleen and possibly maceutical products may therefore be in part avoided.

One more point of importance eems to be logically deduced from our work. The results indicate a like from the administration of these nuclear extractives in both primary and secondary anemias. Modifying factors may enter both groups and revent or alter type blood reactions.

(6) Proc Soc. Exp. Biol. \& Med., 1928 $\mathrm{xxv}: 255$ 